\title{
PENGARUH \\ PUPUK ZA DAN KOMPOS TERHADAP KANDUNGAN Pb, Zn, Cu DAN N TANAH SERTA HASIL TANAMAN PADA SISTEM BUDIDAYA BAWANG MERAH DI TEPI DANAU BATUR, KINTAMANI, BANGLI
}

\author{
Shinta Lestari Santosa ${ }^{1 *}$, I Nyoman Rai ${ }^{2)}$, Wayan Diara ${ }^{2)}$ \\ ${ }^{1)}$ Dinas Lingkungan Hidup, Kabupaten Jembrana \\ ${ }^{2)}$ Program Studi Agroteknologi, Fakultas Pertanian Universitas Udayana \\ *Email: shintalestari881@gmail.com
}

\begin{abstract}
THE EFFECT OF ZA FERTILIZER AND COMPOST ON Pb, Zn, Cu, N OF SOIL AND YIELDS OF SHALLOTS CULTIVATION IN THE SIDE OF LAKE BATUR, KINTAMANI, BANGLI
\end{abstract}

\begin{abstract}
Vegetable cultivation is livelihoods for side Lake Batur communities, Kintamani, Bangli. Hilly natural conditions with a soil texture influenced by the eruption of Mount Batur, $900 \mathrm{~m}$ above sea level, and 900-3500 $\mathrm{mm}$ high rainfall, causing this region is very suitable for the cultivation of various vegetables, including shallot. One effort to meet the high demand for shallots is that efforts are made to improve cultivation techniques, including fertilizing to improve yields. In modern agriculture, the use of fertilizer is absolutely essential to trigger the level of crop production. The aims is to analyze the combination effect of using of inorganic fertilizer (ZA fertilizer) and organic fertilizer (compost fertilizer) on shallot vegetable cultivation systems on the content of pollutants, $\mathrm{N}$ nutrients and onion crop yields on the shores of Lake Batur, Kintamani District, Bangli Regency. The study using RBD with two factors where factor I: provision of organic fertilizer is leaf compost made aerobically $(\mathrm{O})$, consisted of 3 levels, namely: $\mathrm{O}_{0}=0^{*}, \mathrm{O}_{1}=5^{*}$ and $\mathrm{O}_{2}=10 *$ and factor II: the application of inorganic fertilizer namely ZA $(S)$ fertilizer, consisted of 3 levels, namely: $S_{0}=$ $0^{* *}, \mathrm{~S}_{1}=50^{* *}$ and $\mathrm{S}_{2}=100^{* *}$, each repeated 3 times. The parameters observed were the growth and yield of shallots as well as the content of $\mathrm{Pb}, \mathrm{Zn}, \mathrm{Cu}$ and $\mathrm{N}$ nutrients in the soil. The nutrient content $(\mathrm{N})$ in the soil, when using chemical fertilizer ZA and compost organic is not significantly different, as well as the results of onion plants, while the content of $\mathrm{Pb}, \mathrm{Zn}$ and $\mathrm{Cu}$ on the use of chemical fertilizer ZA and organic compost, very real different. The highest soil $\mathrm{Pb}$ content in $\mathrm{S}_{2} \mathrm{O}_{1}$ treatment is $30.07 * * *$, the highest soil $\mathrm{Zn}$ content in the $\mathrm{S}_{2} \mathrm{O}_{1}$ treatment was $28.24 * * *$, and the highest soil $\mathrm{Cu}$ content in the $\mathrm{S}_{1} \mathrm{O}_{2}$ treatment is $17.22 * * *$.

$*=$ tons $/$ ha

$* *=\mathrm{kg} / \mathrm{ha}$

$* * *=\mathrm{mg} / \mathrm{kg}$
\end{abstract}

Keywords: compost; contents $\mathrm{Pb}$; Zn; $\mathrm{Cu}$ of soil; shallot; ZA.

\section{PENDAHULUAN}

Kondisi alam tepi Danau Batur, Kintamani, Bangli, yang berbukit dengan tekstur tanah regosol yang sebagian kasar, dengan kedalaman tanah efektif 30-90 cm, pada ketinggian 900 mdpl mengakibatkan wilayah ini sangat cocok digunakan untuk budidaya tanaman sayur, terutama pada area dengan jenis Regosol Coklat Kekuningan (regosol berhumus). Komoditas hortikultura mempunyai permintaan tinggi, nilai jual pun bagus. Potensi pengembangan bawang 
merah sangat bagus, baik untuk kebutuhan domestik dan luar negeri (Suriani, 2011).

Cara untuk memenuhi kebutuhan sayur yang meningkat, salah satunya dengan melakukan usaha-usaha perbaikan dalam teknik budidaya, diantaranya pemupukan yang dilakukan untuk meningkatkan hasil panen. Pupuk diartikan sebagai bahan yang berguna mengubah sifat-sifat fisika, kimia dan biologi tanah menjadi lebih baik. Prihmantoro (1999) mengemukakan pupuk diperlukan untuk tercukupinya unsur hara sehingga mampu mencapai produksi yang tinggi serta kualitas hasil tanaman yang bagus. Dalam pertanian modern, pemakaian pupuk mutlak untuk meningkatkan produksi sayuran. Pupuk beredar dalam ragam jenis, bentuk, berat, dan kemasan.

Namun, ancaman serius muncul saat sebagian besar pertanian di tepi Danau Batur masih menggunakan pupuk anorganik yaitu pupuk ZA, meskipun banyak penelitian telah menyimpulkan bahwa pupuk anorganik dapat menimbulkan terjadinya kerusakan lingkungan (Benbrook, 1991). Pupuk ZA hamper serupa dengan pupuk urea karena sama-sama memiliki kandungan unsur hara $\mathrm{N}$, meskipun jumlahnya lebih rendah daripada pupuk urea, namun akibat penggunaan pupuk ini dapat merusak lingkungan. Dengan letak lahan yang tinggi jika dibanding dengan Danau Batur, serta banyak kegiatan pertanian di tepi danau, menyebabkan banyak rembesan residu masuk ke danau, yaitu: pestisida dan pupuk. Karenanya terjadi penumpukan zat pencemar ke danau (Jibriel, 2014). Residu pupuk dipakai sebagai sumber nutrient bagi biota air. Pupuk mengalir ke danau. Inilah sebabnya tumbuhan air menjadi lebih subur. Namun, dampak yang mengerikan adalah proses eutrofikasi danau menyebabkan mutu air danau berubah atau ada beban pencemaran. Kuncaka (2004) menyebutkan bahwa masyarakat sekitar danau mengkonsumsi air Danau Batur. Untuk mencegah efek pencemaran lingkungan yang lebih lanjut, cara yang dilakukan adalah mengurangi penggunaan pupuk pupuk kimia dan meningkatkan penggunaan pupuk organik. Sehingga penggunaan ini baik juga untuk lingkungan. Selain ramah lingkungan pupuk organik juga jauh lebih efisien dari segi pembiayaan, sehingga tidak akan memberatkan para petani. Keuntungan lain dari pupuk organik adalah pupuk ini mengandung mikroorganisme yang dapat mendegradasi residu pestisida, yang ada di tanah (Indrayani, 2006). Pupuk organik juga bisa memperbaiki sifat fisik, biologis, dan kimia yang menyebabkan tanah subur.

Berdasarkan pertimbangan ini maka dilakukan penelitian untuk melihat pengaruh kombinasi pupuk anorganik (pupuk ZA) dan pupuk organik (pupuk kompos) terhadap kandungan $\mathrm{Pb}, \mathrm{Zn}, \mathrm{Cu}$ dan $\mathrm{N}$ tanah serta hasil tanaman pada sistem budidaya bawang merah di pinggir Danau Batur, Kintamani, Bangli. Dari penelitian ini diharapkan ditemukan pengaruh penggunaan pupuk organik (pupuk kompos) dalam sistem budidaya yang ramah lingkungan dan berkelanjutan. Terdapat tiga masalah yang dijabarkan dalam penelitian ini: apakah kandungan $\mathrm{N}$ tanah pada penggunaan pupuk ZA lebih besar dari pupuk kompos, apakah kandungan $\mathrm{Pb}, \mathrm{Zn}$ dan $\mathrm{Cu}$ pada tanah dengan penggunaan pupuk ZA lebih besar dari pupuk kompos, dan apakah hasil tanaman bawang merah pada penggunaan pupuk ZA lebih rendah dari pupuk kompos. Demikian pun tujuan penelitian, terdapat tiga tujuan, yaitu: menganalisis pengaruh pemakaian pupuk ZA dan pupuk kompos terhadap kandungan $\mathrm{N}$ tanah pada lahan budidaya bawang merah, menganalisis pengaruh pemakaian pupuk ZA dan kompos pada kandungan $\mathrm{Pb}, \mathrm{Zn}$ dan $\mathrm{Cu}$ terhadap lahan budidaya bawang merah, dan menganalisis hasil bawang merah pada penggunaan pupuk ZA dan pupuk kompos.

\section{METODOLOGI}

\subsection{Lokasi Penelitian}

Penelitian dilakukan bulan Maret Mei 2019 di tepi Danau Batur yaitu di Desa Buahan, Kintamani, Bangli. 


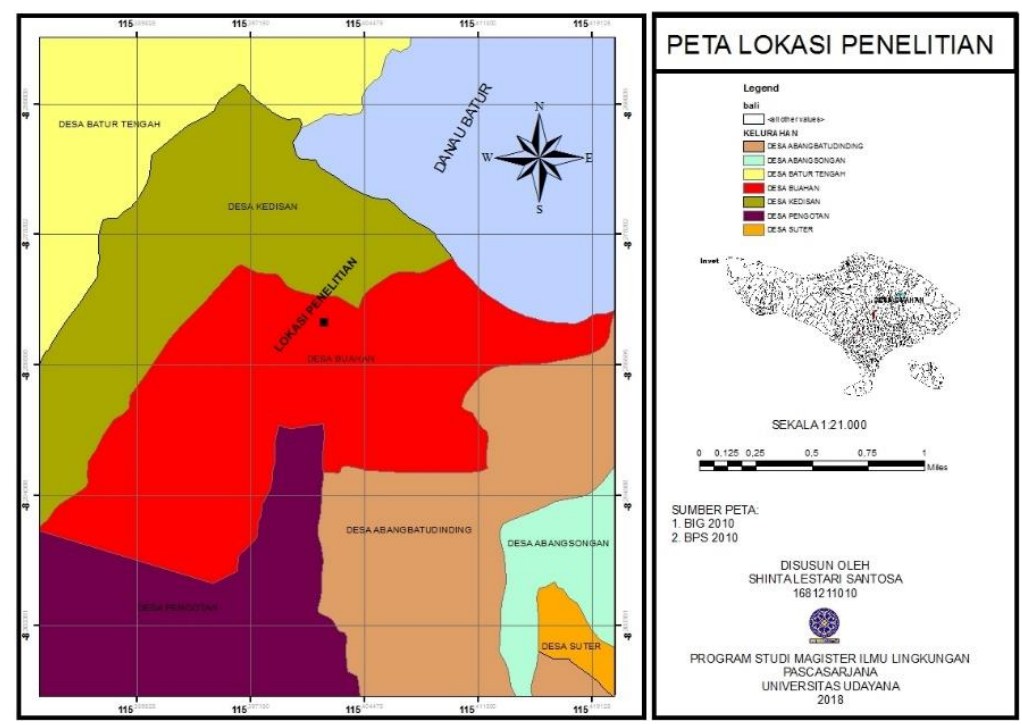

Gambar 1.

Lokasi Penelitian

\subsection{Jenis dan Sumber Data}

Sumber data primer adalah hasil observasi pertumbuhan dan hasil bawang merah serta hasil analisis laboratorium kandungan $\mathrm{Pb}, \mathrm{Zn}, \mathrm{Cu}$ dan $\mathrm{N}$ dalam tanah hasil budidaya pertanian organik dan anorganik. Untuk data sekunder, didapat dari buku dan jurnal nasional/internasional serta wawancara dengan petani lokal. Variabel diamati dalam penelitian ini: kandungan $\mathrm{Pb}$, $\mathrm{Zn}$ dan $\mathrm{Cu}$, kandungan $\mathrm{N}$ tanah, pertumbuhan tanaman, dan hasil bawang merah.

\subsection{Populasi dan Sampel}

Pertumbuhan bawang merah yang diteliti meliputi: berat segar umbi per tanaman, jumlah daun, berat segar tanaman, tinggi tanaman, berat kering oven tanaman, berat kering oven umbi per tanaman, berat segar umbi per hektar, dan berat kering oven umbi per hektar.

\subsection{Instrumen Penelitian}

Instrumen penelitian ini meliputi: bibit tanaman bawang merah, tanah yang dihomogenasi, pupuk organik (pupuk kompos yang dibuat secara aerob), pupuk anorganik (pupuk ZA), pestisida sintetik (rizotin) dan biopestisida (biolove). Adapun alat yang dibutuhkan, seperti: plat percobaan 27 buah, plastik berlubang, timbangan digital, penyemprotan, selang air, meteran gulung, cangkul mini, ember dan peralatan tulis. Pemilihan parameter analisis tanah tergantung pada tujuan penelitian. Pemilihan parameter yang tepat akan membantu mencapai tujuan, efisien dan efektif dalam biaya. Metode analisis yang digunakan bergantung pada ketersediaan alat dan bahan kimia, keahlian tenaga teknis, dan tingkat akurasi yang ingin dicapai dalam tujuan penelitian. Untuk analisis $\mathrm{N}$ tanah digunakan metode Kjeldahl. Untuk analisis $\mathrm{Pb}, \mathrm{Zn}$ dan $\mathrm{Cu}$ digunakan metode AAS dengan jenis AAS Shimadzu AA-7000.

\subsection{Teknik Pengumpulan Data}

1. Pengambilan sampel untuk analisis kandungan $\mathrm{Pb}, \mathrm{Zn}, \mathrm{Cu}$ dan $\mathrm{N}$ tanah. Penentuan lokasi menggunakan metode purposive sampling. Sampel tanah diambil dua kali yaitu pada awal persiapan lahan dimana ditentukan 9 titik pada lahan percobaan yang mewakili kegiatan pertanian di tepi Danau Batur tepatnya di Desa Buahan, Kintamani, Bangli. Kesembilan titik lokasi pengambilan sampel di komposit sehingga mendapatkan sampel yang homogen. Pengambilan sampel tanah 
kedua dilakukan sesudah panen. Penentuan titik lokasi pengambilan sampel tanah sesudah panen dilakukan di masing-masing 27 petak percobaan.

2. Persiapan lahan. Lahan bekas budidaya tanaman hortikultura bawang merah dengan menggunakan pupuk anorganik selama kurang lebih 6 sampai 7 tahun digunakan dalam penelitian ini. Pada tahap awal persiapan lahan, tanah diberikan sekam yang ditambahkan pupuk kandang sebagai pupuk dasar dengan komposisi 1:1 dengan dosis

masing-masing untuk sekam dan pupuk kandang yaitu 5 ton/ha atau 0,825 $\mathrm{kg} /$ petak untuk semua petak baik yang mendapatkan perlakuan organik maupun anorganik. Kemudian tanah digemburkan dengan cangkul dan traktor yang kemudian dilanjutkan dengan pemasangan plastik berlubang pada permukaan tanah. Pembentukan petak pada pengolahan tanah kedua dilakukan dengan ukuran $(1,5 \times 1,1) \mathrm{m}^{2}$. Tata letak didenahkan seperti pada Gambar 2.
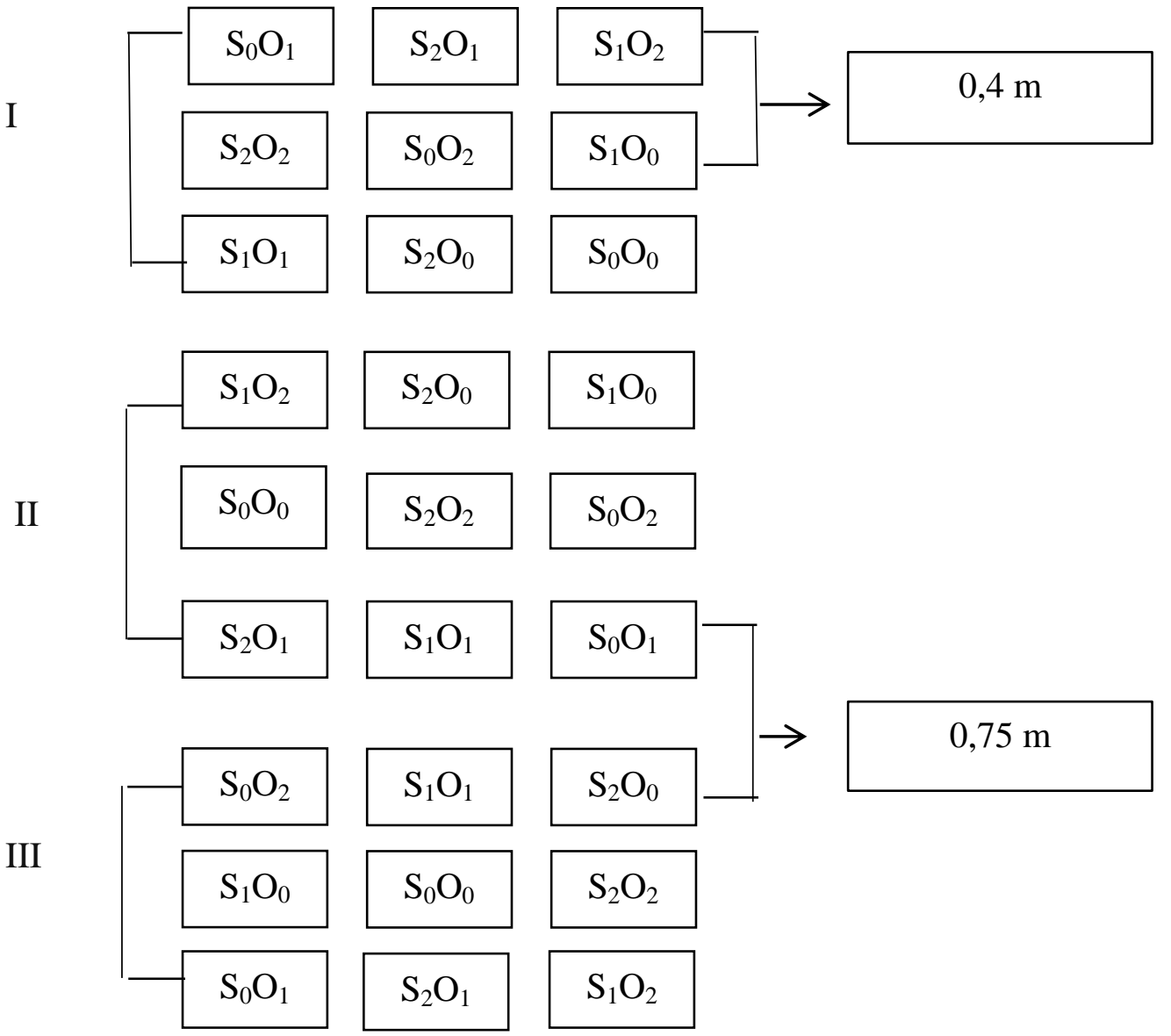

$$
\mathrm{S}_{2} \mathrm{O}_{2}
$$

$\mathrm{S}_{1} \mathrm{O}_{2}$

Gambar 2.

Denah Tata Letak Petak Percobaan

3. Penanaman. Penanaman dilakukan secara mekanis dengan 1 bibit per lubang. Kedalaman yang dibuat adalah $10-15$ $\mathrm{cm}$. Jarak tanam diukur $25 \mathrm{~cm} \times 25 \mathrm{~cm}$. Tanaman bawang ditanam pada lubanglubang yang disiapkan dan disiram setiap hari. Setiap satu petak terdiri dari 35 tanaman yang disusun $7 \times 5$ yaitu 7 bibit tanaman ditanam secara horizontal dan 5 ditanam secara vertikal.
4. Pemupukan. Tahapan proses pemupukan dilakukan, adalah sebagai berikut:

- Pemupukan organik: pemupukan dilakukan diawal penanaman dengan menggunakan pupuk kompos dengan dosis $\mathrm{O}_{0}=0$ ton/ha, $\mathrm{O}_{1=} 5$ ton/ha atau $0,825 \mathrm{~kg} /$ petak dan $\mathrm{O}_{2}=10$ ton $/ \mathrm{ha}$ atau $1,65 \mathrm{~kg} /$ petak, kemudian untuk penyemprotan biopestisida dilakukan 
selang 3-4 hari setelah pemberian pupuk organik padat.

- Pemupukan anorganik: pemupukan dilakukan diawal penanaman dengan memakai pupuk kimia padat (pupuk $\mathrm{ZA}$ ) dengan dosis $\mathrm{S}_{0=} 0 \mathrm{~kg} / \mathrm{ha}, \mathrm{S}_{1}=50$ $\mathrm{kg} / \mathrm{ha}$ atau $0,00825 \mathrm{~kg} /$ petak atau $8,25 \mathrm{gram} / \mathrm{petak}$ dan $\mathrm{S}_{2}=100 \mathrm{~kg} / \mathrm{ha}$ atau $0,0165 \mathrm{~kg} /$ petak atau 16,5 gram/petak, kemudian untuk penyemprotan pestisida anorganik dilakukan sebanyak dua kali yaitu 30 hari sekali.

- Proses tersebut diulang setiap 20 hari sekali.

5. Pemeliharaan tanaman dengan pengendalian hama penyakit, penyiangan gulma, dan penyiraman. Tiap hari, dilakukan penyiraman yang sangat hatihati karena terkait dengan jumlah air yang diberikan pada setiap petak harus sama, apabila penyiraman tidak sama, nanti hasilnya kurang akurat, bukan karena pengaruh perlakukan yang diberikan, tetapi karena penyiraman. Penyiangan dilakukan 3 kali dengan cangkul kecil, sabit atau dengan tangan saat pada umur 21, 35 dan 55 hari. Pengendalian penyakit secara intensif dilakukan sesuai PHT.

6. Proses panen dikerjakan setelah tanaman berumur 60-70 hari. Proses panen dilakukan dengan melakukan pencabutan tanaman bawang merah hingga bagian akar. Lalu di setiap petak, hasil panen diikat untuk bisa dianalisa lebih lanjut.

\subsection{Analisis Laboratorium}

Untuk analisis kandungan $\mathrm{Pb}, \mathrm{Zn}$ dan $\mathrm{Cu}$ digunakan metode AAS, cara kerja yang dilakukan, adalah sebagai berikut. Penambahan $1 \mathrm{ml}$ asam perklorat p.a dan 5 $\mathrm{ml}$ asam nitrat p.a dilakukan setelah penimbangan $1,000 \mathrm{~g}$ contoh ke dalam tabung digest, kemudian didiamkan satu malam. Lalu dipanaskan pada suhu $100^{\circ} \mathrm{C}$ selama 1,5 jam. Suhu dinaikkan menjadi $130^{\circ} \mathrm{C}$ selama 1 jam, suhu ditingkatkan menjadi $150^{\circ} \mathrm{C}$ selama 2 jam 30 menit. Proses ini dilakukan hingga uap kuning habis. Bila ternyata uap kuning masih ada, waktu pemanasan akan ditambahkan. Bila uap kuning habis, suhu akan dinaikkan menjadi $170^{\circ}$ C. Setelah 1 jam, suhu ditingkatkan menjadi $200^{\circ} \mathrm{C}$ selama 1 jam hingga mendapatkan uap putih. Destruksi dinyatakan selesai saat ada endapan putih atau sisa larutan jernih sekitar $1 \mathrm{ml}$. Ekstrak didinginkan kemudian diencerkan dengan air bebas ion menjadi $10 \mathrm{ml}$, lalu dikocok. Sampel yang telah di preperasi selanjutnya di analisa dengan alat-alat AAS, prosedur kerja untuk pengoperasian analisa tersebut dengan memakai panjang gelombang: $\mathrm{Pb} 217 \mathrm{~nm}$, $\mathrm{Cu} 324,8 \mathrm{~nm}$ dan $\mathrm{Zn} 21,9 \mathrm{~nm}$.

Untuk penghitungan kadar nitrogen menggunakan metode Kjeldahl. Langkahlangkah dalam metode ini sebagai berikut: preparasi sampel, pelepasan ikatan, penyulingan, dan titrasi. Tujuan preparasi sampel adalah untuk membuat sampel hingga siap untuk dilakukan langkah berikutnya, yaitu pelepasan ikatan. Bila sampel padat, sampel digilling dahulu dengan besaran mesh $<1 \mathrm{~mm}$. Bila berupa cairan atau semi solid, sampel sebaiknya diaduk hingga kondisinya homogen. Pelepasan ikatan bertujuan melepaskan ikatan nitrogen dalam protein menjadi ammonium sulfat. Proses ini dilakukan dengan mencampurkan reagent asam sulfat, katalis dan antifoam jika diperlukan. Setelah melakukan pencampuran, campuran dipanaskan. Reaksi kimia yang terjadi sebagai berikut: Sampel $+\mathrm{H}_{2} \mathrm{SO}_{4} \longrightarrow$ $\left(\mathrm{NH}_{4}\right)_{2} \mathrm{SO}_{4}+\mathrm{CO}_{2}+\mathrm{SO}_{2}+\mathrm{H}_{2} \mathrm{O}$ berikut:

Berikut langkah penyulingan, sebagai

Pembebasan ammonia oleh sodium hydrat : $\left(\mathrm{NH}_{4}\right)_{2} \mathrm{SO}_{4}+2 \mathrm{NaOH} \longrightarrow \mathrm{Na}_{2} \mathrm{SO}_{4}$ $+2 \mathrm{H}_{2} \mathrm{O}+2 \mathrm{NH}_{3}$

Pengikatan ammonia oleh asam borik : $\mathrm{B}(\mathrm{OH})_{3}+\mathrm{H}_{2} \mathrm{O}+\mathrm{NH}_{3} \longrightarrow\left(\mathrm{NH}_{4}+\right)$ $+\mathrm{B}(\mathrm{OH})_{4-}$

Setelah itu, penentuan kadar ammonia dapat dilakukan dengan cara titrasi asam basa (colorimetric, potensiometric dan lain-lain). Contoh titrasi dapat dilakukan dengan sodium carbonat. Reaksi titrasi: 
$\mathrm{B}(\mathrm{OH})_{3}+\mathrm{H}_{2} \mathrm{O}+\mathrm{Na}_{2} \mathrm{CO}_{3} \longrightarrow$

$\mathrm{NaHCO}_{3}+\mathrm{NaB}(\mathrm{OH})_{4}+\mathrm{CO}_{2}+\mathrm{H}_{2} \mathrm{O}$

\subsection{Analisa Data}

Pengumpulan data dilanjutkan dengan Anova. Perlakuam ini sesuai dengan rancangan. Jika perlakuan menunjukkan pengaruh nyata sampai sangat nyata, maka dilanjutkan dengan uji beda nilai rata-rata menggunakan uji beda nyata terkecil (BNT taraf 5\%).

\section{HASIL DAN PEMBAHASAN}

\subsection{Signifikansi Pengaruh Perlakuan Pupuk ZA dan Pupuk Kompos}

Hasil analisis statistika menunjukkan terdapat signifikansi pengaruh perlakuan pemupukan ZA (S), pemupukan kompos (O) dan interaksi kedua perlakuan tersebut ( $\mathrm{S} \times$ O) terhadap variabel yang diamati. Hasil analisis varians menunjukkan bahwa perlakuan tunggal pemupukan ZA (S) dan pemupukan kompos (O) maupun interaksi keduanya, berpengaruh sangat nyata terhadap kandungan timbal $(\mathrm{Pb})$, seng $(\mathrm{Zn})$, dan tembaga $(\mathrm{Cu})$. Kemudian untuk kandungan $\mathrm{N}$ tanah setelah panen dengan perlakuan tunggal pemupukan ZA (S) dan pemupukan kompos (O) maupun interaksi keduanya berpengaruh tidak nyata (tn).

Pengaruh perlakuan pemupukan ZA (S) dan perlakuan pemupukan kompos (O) terhadap pertumbuhan serta hasil tanaman yang merangkum tinggi tanaman pada $30 \mathrm{hst}$ dan 70 hst, jumlah daun pada 30 hst dan 70 hst, berat segar tanaman, berat kering oven tanaman, berat segar umbi pertanaman, berat kering oven umbi pertanaman, berat segar umbi per-hektar dan berat kering oven umbi per-hektar adalah berpengaruh tidak nyata (tn). Hasil analisis signifikansi pengaruh perlakuan pupuk ZA (S), kompos (O) dan interaksi ( $\mathrm{S} \times \mathrm{O}$ ) terhadap variabel yang diamati terpapar di Tabel 1.

Tabel 1. Pengaruh Pupuk ZA (S) dan Kompos (O)

\begin{tabular}{lllll}
\hline \multirow{2}{*}{ No. } & \multirow{2}{*}{ Variabel } & \multicolumn{2}{l}{ Perlakuan } \\
\cline { 3 - 5 } & $\mathrm{S}$ & $\mathrm{O}$ & $\mathrm{S} \mathrm{x} \mathrm{O}$ \\
\hline 1. & Pb-tersedia tanah $(\mathrm{mg} / \mathrm{kg})$ & $* *$ & $* *$ & $* *$ \\
2. & Zn-tersedia tanah $(\mathrm{mg} / \mathrm{kg})$ & $* *$ & $* *$ & $* *$ \\
3. & Cu-tersedia tanah $(\mathrm{mg} / \mathrm{kg})$ & $* *$ & $* *$ & $* *$ \\
4. & N tanah $(\%)$ & $\times$ & $\times$ & $\times$ \\
5. & Tinggi tanaman $30 \mathrm{hst}(\mathrm{cm})$ & $\times$ & $\times$ & $\times$ \\
6. & Tinggi tanaman $70 \mathrm{hst}(\mathrm{cm})$ & $\times$ & $\times$ & $\times$ \\
7. & Jumlah daun $30 \mathrm{hst}$ & $\times$ & $\times$ & $\times$ \\
8. & Jumlah daun $70 \mathrm{hst}$ & $\times$ & $\times$ & $\times$ \\
9. & Berat segar tanaman $(\mathrm{g})$ & $\times$ & $\times$ & $\times$ \\
10. & Berat kering oven tanaman $(\mathrm{g})$ & $\times$ & $\times$ & $\times$ \\
11. & Berat segar umbi per tanaman $(\mathrm{g})$ & $\times$ & $\times$ & $\times$ \\
12. & Berat kering oven umbi per tanaman $(\mathrm{g})$ & $\times$ & $\times$ & $\times$ \\
13. & Berat segar umbi per hektar $(\mathrm{g})$ & $\times$ & $\times$ & $\times$ \\
14. & Berat kering oven umbi per hektar $(\mathrm{g})$ & $\times$ & $\times$ & $\times$ \\
\hline
\end{tabular}

Keterangan :

$* \quad=$ berpengaruh nyata $(\mathrm{P}<0,05)$

$* *$ = berpengaruh sangat nyata $(\mathrm{P}<0,01)$

$\times=$ berpengaruh tidak nyata $(P \geq 0,05)$

\subsection{Pengaruh Perlakuan Pupuk ZA - Pupuk Kompos Terhadap Tanah}

\subsubsection{Kandungan $\mathrm{Pb}$ Tanah}

Hasil analisis kandungan $\mathrm{Pb}$ tanah sebelum tanam sebesar ttd (tidak terdeteksi pada limit deteksi alat $0,001 \mathrm{mg} / \mathrm{L}$. Pengaruh perlakuan pemupukan ZA (S) dan kompos (O) terhadap kandungan $\mathrm{Pb}$ setelah panen, lihat Tabel 2. 
Tabel 2. Pengaruh Pemupukan ZA dan Kompos terhadap Kandungan Pb Tanah Setelah Panen

\begin{tabular}{cccl}
\hline \multirow{2}{*}{ Perlakuan } & \multicolumn{3}{c}{ Kandungan $\mathrm{Pb}$ Tanah $(\mathrm{mg} / \mathrm{kg})$} \\
\cline { 2 - 4 } & \multicolumn{1}{c}{$\mathrm{S}_{0}$} & $\mathrm{~S}_{1}$ & \multicolumn{1}{c}{$\mathrm{S}_{2}$} \\
\hline $\mathrm{O}_{0}$ & $16,73 \mathrm{e}$ & $13,44 \mathrm{f}$ & $26,69 \mathrm{bc}$ \\
$\mathrm{O}_{1}$ & $17,75 \mathrm{e}$ & $20,67 \mathrm{~d}$ & $30,07 \mathrm{a}$ \\
$\mathrm{O}_{2}$ & $24,49 \mathrm{c}$ & $24,70 \mathrm{c}$ & $28,75 \mathrm{ab}$ \\
\hline
\end{tabular}

Keterangan: angka-angka yang diikuti huruf yang sama menunjukkan berbeda tidak nyata secara horizontal dan vertikal berdasarkan uji Duncan 5\%.

Berdasarkan Tabel 2 tersebut terlihat bahwa kombinasi perlakuan $\mathrm{S}$ dan $\mathrm{O}$ menunjukkan pengaruh interaksi sangat nyata terhadap kandungan $\mathrm{Pb}$ tanah. Semua perlakuan kombinasi $\mathrm{S}$ dan $\mathrm{O}$ menunjukkan pengaruh interaksi sangat nyata terhadap kandungan $\mathrm{Pb}$ tanah, kecuali perlakuan kombinasi $\mathrm{S}_{0} \mathrm{O}_{1}$. Kombinasi perlakuan $\mathrm{S}_{0} \mathrm{O}_{2}$ berpengaruh sangat nyata dibandingkan perlakuan $\mathrm{S}_{1} \mathrm{O}_{2}, \mathrm{~S}_{2} \mathrm{O}_{0}$ dan $\mathrm{S}_{2} \mathrm{O}_{2}$. Kandungan $\mathrm{Pb}$ tanah tertinggi terdapat pada perlakuan $\mathrm{S}_{2} \mathrm{O}_{1}$ yaitu sebesar $30,07 \mathrm{mg} / \mathrm{kg}$ yang meningkat sebesar $79,74 \%$ dibandingkan dengan perlakuan kontrol $\left(\mathrm{S}_{0} \mathrm{O}_{0}\right)$ yang nilainya hanya $16,73 \mathrm{mg} / \mathrm{kg}$. Jika dibandingkan dengan perlakuan $\mathrm{S}_{0} \mathrm{O}_{2}(24,49$ $\mathrm{mg} / \mathrm{kg}$ ), maka perlakuan $\mathrm{S}_{2} \mathrm{O}_{1}$ terdapat peningkatan sebesar 22,78\%. Adapun pengaruh interaksi dari perlakuan pupuk ZA dan kompos pada perlakuan $\mathrm{S}_{2} \mathrm{O}_{1}$ terhadap kandungan $\mathrm{Pb}$ dalam tanah tertinggi disebabkan oleh pupuk ZA banyak mengandung nitrogen (N) sebanyak 20,8\% dalam bentuk amonium dan sulfur atau belerang (S) sebanyak 23,8\%.

\subsubsection{Kandungan Zn Tanah}

Hasil analisis kandungan $\mathrm{Zn}$ tanah sebelum tanam sebesar $91,017 \mathrm{mg} / \mathrm{kg}$. Pengaruh perlakuan pemupukan ZA (S) dan kompos (O) terhadap kandungan $\mathrm{Zn}$ setelah panen disajikan pada Tabel 3.

Tabel 3.Pengaruh Pemupukan ZA dan Kompos terhadap Kandungan Zn Tanah Setelah Panen

\begin{tabular}{cccc}
\hline \multirow{2}{*}{ Perlakuan } & \multicolumn{3}{c}{ Kandungan Zn Tanah $(\mathrm{mg} / \mathrm{kg})$} \\
\cline { 2 - 4 } & $\mathrm{S}_{0}$ & $\mathrm{~S}_{1}$ & $\mathrm{~S}_{2}$ \\
\hline $\mathrm{O}_{0}$ & $25,15 \mathrm{~b}$ & $25,47 \mathrm{~b}$ & $19,44 \mathrm{e}$ \\
$\mathrm{O}_{1}$ & $24,22 \mathrm{c}$ & $18,64 \mathrm{fg}$ & $28,24 \mathrm{a}$ \\
$\mathrm{O}_{2}$ & $18,95 \mathrm{ef}$ & $21,76 \mathrm{~d}$ & $18,31 \mathrm{~g}$ \\
\hline
\end{tabular}

Keterangan: Angka-angka yang diikuti huruf yang sama menunjukkan berbeda tidak nyata secara horizontal dan vertikal berdasarkan uji Duncan 5\%.

Berdasarkan Tabel 3 tersebut terlihat bahwa kombinasi perlakuan $\mathrm{S}$ dan $\mathrm{O}$ menunjukkan pengaruh interaksi sangat nyata terhadap kandungan $\mathrm{Zn}$ tanah. Semua perlakuan kombinasi $\mathrm{S}$ dan $\mathrm{O}$ menunjukkan pengaruh interaksi sangat nyata terhadap kandungan $\mathrm{Zn}$ tanah, kecuali perlakuan kombinasi $\mathrm{S}_{1} \mathrm{O}_{0}$. Kombinasi perlakuan $\mathrm{S}_{0} \mathrm{O}_{2}$ berpengaruh sangat nyata dibandingkan perlakuan $\mathrm{S}_{1} \mathrm{O}_{1}, \mathrm{~S}_{2} \mathrm{O}_{0}$ dan $\mathrm{S}_{2} \mathrm{O}_{2}$. Kandungan $\mathrm{Zn}$ tanah tertinggi terdapat pada perlakuan $\mathrm{S}_{2} \mathrm{O}_{1}$ yaitu sebesar $28,24 \mathrm{mg} / \mathrm{kg}$ yang meningkat sebesar 12,29\% dibandingkan dengan perlakuan kontrol $\left(\mathrm{S}_{0} \mathrm{O}_{0}\right)$ yang nilainya hanya $25,15 \mathrm{mg} / \mathrm{kg}$. Jika dibandingkan dengan perlakuan $\mathrm{S}_{0} \mathrm{O}_{2}(18,95$ $\mathrm{mg} / \mathrm{kg}$ ), maka perlakuan $\mathrm{S}_{2} \mathrm{O}_{1}$ terdapat peningkatan sebesar $49 \%$.

Adapun pengaruh interaksi dari perlakuan pupuk ZA dan kompos pada perlakuan $\mathrm{S}_{2} \mathrm{O}_{1}$ terhadap kandungan $\mathrm{Zn}$ dalam tanah disebabkan karena pupuk kimia mampu meningkatkan kadar $\mathrm{Zn}$ dalam tanah sedangkan pupuk organik cenderung menurunkan. 


\subsubsection{Kandungan Cu Tanah}

Hasil analisis kandungan $\mathrm{Cu}$ tanah sebelum tanam sebesar $87,191 \mathrm{mg} / \mathrm{kg}$.
Pengaruh perlakuan pemupukan ZA (S) dan kompos $(\mathrm{O})$ terhadap kandungan $\mathrm{Cu}$ setelah panen, lihat Tabel 4.

Tabel 4. Pengaruh Pemupukan ZA dan Kompos terhadap Kandungan Cu Tanah Setelah Panen

\begin{tabular}{cccc}
\hline \multirow{2}{*}{ Perlakuan } & \multicolumn{3}{c}{ Kandungan Cu Tanah $(\mathrm{mg} / \mathrm{kg})$} \\
\cline { 2 - 4 } & $\mathrm{S}_{0}$ & $\mathrm{~S}_{1}$ & $\mathrm{~S}_{2}$ \\
\hline $\mathrm{O}_{0}$ & $14,79 \mathrm{~b}$ & $10,47 \mathrm{f}$ & $12,47 \mathrm{~d}$ \\
$\mathrm{O}_{1}$ & $14,67 \mathrm{~b}$ & $10,88 \mathrm{ef}$ & $16,71 \mathrm{a}$ \\
$\mathrm{O}_{2}$ & $11,37 \mathrm{e}$ & $17,22 \mathrm{a}$ & $13,76 \mathrm{c}$ \\
\hline
\end{tabular}

Keterangan: angka-angka yang diikuti huruf yang sama menunjukkan berbeda tidak nyata secara horizontal dan vertikal berdasarkan uji Duncan 5\%.

Berdasarkan Tabel 4 kombinasi perlakuan $\mathrm{S}$ dan $\mathrm{O}$ menunjukkan pengaruh interaksi sangat nyata terhadap kandungan $\mathrm{Cu}$ tanah. Semua perlakuan kombinasi S dan $\mathrm{O}$ menunjukkan pengaruh interaksi sangat nyata terhadap kandungan $\mathrm{Cu}$ tanah, kecuali perlakuan kombinasi $\mathrm{S}_{0} \mathrm{O}_{1}$. Kombinasi perlakuan $\mathrm{S}_{0} \mathrm{O}_{2}$ berpengaruh sangat nyata dibandingkan perlakuan $\mathrm{S}_{1} \mathrm{O}_{1}$ dan $\mathrm{S}_{1} \mathrm{O}_{0}$. Begitu juga dengan kombinasi perlakuan $\mathrm{S}_{1} \mathrm{O}_{2}$ yang berpengaruh sangat nyata dibandingkan perlakuan $\mathrm{S}_{2} \mathrm{O}_{1}$. Kandungan $\mathrm{Cu}$ tanah tertinggi terdapat pada perlakuan $\mathrm{S}_{1} \mathrm{O}_{2}$ yaitu sebesar $17,22 \mathrm{mg} / \mathrm{kg}$ yang meningkat sebesar $16,43 \%$ dibandingkan dengan perlakuan kontrol $\left(\mathrm{S}_{0} \mathrm{O}_{0}\right)$ yang nilainya hanya $14,79 \mathrm{mg} / \mathrm{kg}$. Jika dibandingkan dengan perlakuan $\mathrm{S}_{0} \mathrm{O}_{2}(11,37$ $\mathrm{mg} / \mathrm{kg}$ ), maka perlakuan $\mathrm{S}_{1} \mathrm{O}_{2}$ terdapat peningkatan sebesar 51,45 \%. Adapun pengaruh interaksi dari perlakuan pupuk ZA dan pupuk kompos pada perlakuan $\mathrm{S}_{1} \mathrm{O}_{2}$ terhadap kandungan $\mathrm{Cu}$ dalam tanah disebabkan oleh karena pupuk ZA banyak mengandung nitrogen $(\mathrm{N})$ yaitu sebanyak $21 \%$ dalam bentuk amonium dan sulfur atau belerang (S) sebanyak $24 \%$.

\subsubsection{Kandungan N Tanah}

Hasil analisis kandungan $\mathrm{N}$ tanah sebelum tanam sebesar $0,25 \%$, sehingga nilai tersebut masuk dalam kriteria kandungan $\mathrm{N}$ tanah sedang (S), sedangkan hasil pengukuran kandungan $\mathrm{N}$ setelah panen karena pengaruh perlakuan pemupukan ZA (S) dan kompos (O), lihat Tabel 5 .

Tabel 5. Pengaruh Pemupukan ZA dan Kompos terhadap Kandungan N Tanah Setelah Panen

\begin{tabular}{cc}
\hline Perlakuan & Kandungan N Tanah (\%) \\
\hline (Pemupukan ZA) $\mathrm{S}_{0}$ & $0,140 \mathrm{a}$ \\
(Pemupukan ZA) $\mathrm{S}_{1}$ & $0,129 \mathrm{a}$ \\
(Pemupukan ZA) $\mathrm{S}_{2}$ & $0,133 \mathrm{a}$ \\
\hline BNT 5\% & - \\
\hline (Pemupukan Kompos) $\mathrm{O}_{0}$ & $0,131 \mathrm{a}$ \\
(Pemupukan Kompos) $\mathrm{O}_{1}$ & $0,139 \mathrm{a}$ \\
(Pemupukan Kompos) $\mathrm{O}_{2}$ & $0,132 \mathrm{a}$ \\
\hline BNT 5\% & - \\
\hline
\end{tabular}

Keterangan: menunjukkan berbeda tidak nyata, berdasarkan uji BNT 5\%. 
Dari Tabel 5 perlakuan pemupukan ZA terhadap kandungan $\mathrm{N}$ tanah berbeda tidak nyata antara kontrol $\left(\mathrm{S}_{0}\right)$ dengan pemupukan ZA dosis $50 \mathrm{~kg} / \mathrm{ha}\left(\mathrm{S}_{1}\right)$ dan pemupukan ZA dosis $100 \mathrm{~kg} / \mathrm{ha}\left(\mathrm{S}_{2}\right)$. Namun demikian, ada kecenderungan nilai tertinggi kandungan $\mathrm{N}$ tanah diperoleh pada $\mathrm{S}_{0}$ dengan nilai $0,140 \%$. Setelah diberi perlakuan dosis $50 \mathrm{~kg} / \mathrm{ha}\left(\mathrm{S}_{1}\right)$, kandungan hara $\mathrm{N}$ tanah turun menjadi $0,129 \%$, kemudian setelah diberi perlakuan $100 \mathrm{~kg} / \mathrm{ha}$ $\left(\mathrm{S}_{2}\right)$, naik lagi menjadi 0,133\%.

Pada perlakuan pemupukan kompos dapat juga dilihat antara perlakuan tanpa pupuk kompos sebagai kontrol $\left(\mathrm{O}_{0}\right)$ dengan pemupukan kompos dosis 5 ton/ha $\left(\mathrm{O}_{1}\right)$ dan pemupukan kompos dosis 10 ton/ha $\left(\mathrm{O}_{2}\right)$ berbeda tidak nyata. Hal ini disebabkan bahwa perlakuan dengan pemupukan kompos tidak begitu memberi pengaruh yang signifikan terhadap kandungan $\mathrm{N}$ tanah. Sehingga dapat dilihat pada Tabel 5 ada kecenderungan nilai tertinggi kandungan $\mathrm{N}$ tanah diperoleh pada pada perlakuan $\mathrm{O}_{1}$ yaitu sebesar 0,139\%, atau lebih tinggi sekitar $6,18 \%$.

\subsection{Pengaruh Perlakuan Pupuk ZA dan Pupuk Kompos Terhadap Pertumbuhan dan Hasil}

\subsubsection{Tinggi Tanaman dan Jumlah Daun}

Tabel 6. Pengaruh Pemupukan ZA dan Kompos terhadap Tinggi Tanaman dan Jumlah Daun

\begin{tabular}{ccccc}
\hline Perlakuan & \multicolumn{2}{c}{ Tinggi Tanaman $(\mathrm{cm})$} & \multicolumn{2}{c}{ Jumlah Daun (helai) } \\
\cline { 2 - 5 } & $30 \mathrm{hst}$ & $70 \mathrm{hst}$ & $30 \mathrm{hst}$ & $70 \mathrm{hst}$ \\
\hline (Pemupukan ZA) $\mathrm{S}_{0}$ & $37,16 \mathrm{a}$ & $43,511 \mathrm{a}$ & $38,222 \mathrm{a}$ & $45,667 \mathrm{a}$ \\
(Pemupukan ZA) $\mathrm{S}_{1}$ & $37,24 \mathrm{a}$ & $44,022 \mathrm{a}$ & $38,222 \mathrm{a}$ & $45,667 \mathrm{a}$ \\
(Pemupukan ZA) $\mathrm{S}_{2}$ & $37,31 \mathrm{a}$ & $44,089 \mathrm{a}$ & $38,778 \mathrm{a}$ & $46,000 \mathrm{a}$ \\
\hline BNT 5\% & - & - & - & - \\
\hline (Pemupukan kompos) $\mathrm{O}_{0}$ & $37,47 \mathrm{a}$ & $43,956 \mathrm{a}$ & $39,111 \mathrm{a}$ & $46,000 \mathrm{a}$ \\
(Pemupukan kompos) $\mathrm{O}_{1}$ & $36,84 \mathrm{a}$ & $43,600 \mathrm{a}$ & $38,444 \mathrm{a}$ & $45,667 \mathrm{a}$ \\
(Pemupukan kompos) $\mathrm{O}_{2}$ & $37,40 \mathrm{a}$ & $44,067 \mathrm{a}$ & $37,667 \mathrm{a}$ & $45,667 \mathrm{a}$ \\
\hline
\end{tabular}
BNT 5\%

Keterangan: angka-angka yang diikuti huruf yang sama pada kolom sama menunjukkan berbeda tidak nyata, berdasarkan uji BNT 5\%.

Berdasarkan Tabel 6, pemupukan ZA tinggi tanaman pada 30 hst hasilnya berbeda tidak nyata antara kontrol $\left(\mathrm{S}_{0}\right)$ dengan pemupukan ZA dosis $50 \mathrm{~kg} / \mathrm{ha}\left(\mathrm{S}_{1}\right)$ dan dengan pemupukan ZA dosis $100 \mathrm{~kg} / \mathrm{ha}\left(\mathrm{S}_{2}\right)$. Oleh karena itu, ada kecenderungan tinggi tanaman bawang merah pada 30 hst tertinggi terletak pada perlakuan pemupukan ZA dosis $100 \mathrm{~kg} / \mathrm{ha}\left(\mathrm{S}_{2}\right)$ yaitu $37,31 \mathrm{~cm}$ atau lebih tinggi sekitar $0,40 \mathrm{~cm}$. Hasil analisis data tinggi tanaman pada perlakuan pemupukan kompos antara kontrol $\left(\mathrm{O}_{0}\right)$ dengan pemupukan kompos dosis 5 ton/ha $\left(\mathrm{O}_{1}\right)$ dan dengan pemupukan kompos dosis 10 ton/ha $\left(\mathrm{O}_{2}\right)$ pada 30 hst hasilnya menunjukkan berbeda tidak nyata. Ada kecenderungan tinggi tanaman dengan perlakuan pemupukan kompos (O) tertinggi terdapat pada perlakuan pemupukan kontrol $\left(\mathrm{O}_{0}\right)$ yaitu $37,47 \mathrm{~cm}$.

\subsubsection{Berat Tanaman dan Berat Umbi Tanaman Bawang Merah}

Perlu dilakukan perbandingan hasil tanaman (hasil panen) sebelum diberi perlakuan pemupukan dengan hasil tanaman (hasil panen) setelah diberi perlakuan pemupukan. Hal ini dianggap perlu dilakukan untuk mengetahui adanya pengaruh dari perlakuan pemupukan terhadap hasil tanaman. Hasil panen tanaman 
bawang merah sebelum diberi perlakuan pemupukan rata-rata sebesar 15 ton/ha setiap tahun (Informasi PPL Desa Buahan, Kecamatan Kintamani, Kabupaten Bangli).

Tabel 7. Pengaruh Pemupukan ZA dan Kompos terhadap Berat Segar, Berat Kering Oven dan Berat Umbi

\begin{tabular}{|c|c|c|c|c|c|c|}
\hline \multirow[t]{2}{*}{ Perlakuan } & \multicolumn{3}{|c|}{ Berat Segar (gr) } & \multicolumn{3}{|c|}{ Berat kering (gr) } \\
\hline & $\begin{array}{c}\text { Berat segar } \\
\text { tanaman }\end{array}$ & $\begin{array}{c}\text { Berat } \\
\text { segar } \\
\text { umbi tan } \\
\end{array}$ & $\begin{array}{l}\text { Berat segar } \\
\text { umbi ha }^{-1}\end{array}$ & $\begin{array}{c}\text { Berat kering } \\
\text { oven } \\
\text { tanaman }\end{array}$ & $\begin{array}{c}\text { Berat kering } \\
\text { oven umbi } \\
\tan ^{-1}\end{array}$ & $\begin{array}{l}\text { Berat kering } \\
\text { oven umbi ha } \\
1\end{array}$ \\
\hline \multicolumn{7}{|c|}{ Pemupukan ZA } \\
\hline $\mathrm{S}_{0}$ & $172,937 \mathrm{a}$ & $88,078 \mathrm{a}$ & $1.409 .255 \mathrm{a}$ & 40,437 a & $22,533 \mathrm{a}$ & $360.533 \mathrm{a}$ \\
\hline $\mathrm{S}_{1}$ & $175,409 \mathrm{a}$ & 87,310 a & $1.396 .964 \mathrm{a}$ & 43,849 a & $24,600 \mathrm{a}$ & $393.600 \mathrm{a}$ \\
\hline $\mathrm{S}_{2}$ & $180,638 \mathrm{a}$ & 91,437 a & $1.462 .990 \mathrm{a}$ & 49,993 a & $28,422 \mathrm{a}$ & $454.756 \mathrm{a}$ \\
\hline BNT 5\% & - & - & - & - & - & - \\
\hline \multicolumn{7}{|c|}{ Pemupukan kompos } \\
\hline $\mathrm{O}_{0}$ & 180,917 a & $91,632 \mathrm{a}$ & $1.466 .108 \mathrm{a}$ & $48,354 \mathrm{a}$ & $27,22 \mathrm{a}$ & $435.556 \mathrm{a}$ \\
\hline $\mathrm{O}_{1}$ & $170,126 \mathrm{a}$ & 84,907 a & $1.358 .507 \mathrm{a}$ & $31,801 \mathrm{a}$ & $17,38 \mathrm{a}$ & $278.044 \mathrm{a}$ \\
\hline $\mathrm{O}_{2}$ & $177,941 \mathrm{a}$ & 90,287 a & $1.444 .594 \mathrm{a}$ & 54,123 a & 30,96 a & $495.289 \mathrm{a}$ \\
\hline BNT 5\% & - & - & - & - & - & - \\
\hline
\end{tabular}

Keterangan: menunjukkan berbeda tidak nyata, berdasarkan uji BNT 5\%.

Berdasarkan Tabel 7 parameter berat segar tanaman meliputi berat segar tanaman, berat segar umbi $\tan ^{-1}$ dan berat segar umbi $\mathrm{ha}^{-1}$ pada perlakuan pemupukan ZA berat segar tanaman berbeda tidak nyata antara kontrol $\left(\mathrm{S}_{0}\right)$ dengan pemupukan ZA dosis 50 $\mathrm{kg} / \mathrm{ha}\left(\mathrm{S}_{1}\right)$ dan dengan pemupukan ZA dosis $100 \mathrm{~kg} / \mathrm{ha}\left(\mathrm{S}_{2}\right)$. Hal ini bisa dilihat dari hasil analisis baik dari hasil analisis berat segar tanaman, berat segar umbi $\tan ^{-1}$ maupun berat segar umbi ha ${ }^{-1}$. Berat segar tanaman tertinggi cenderung diperoleh pada perlakuan $\left(\mathrm{S}_{2}\right)$ dengan nilai 180,638 gr atau lebih tinggi sekitar 4,45 gr, sedangkan untuk berat segar umbi $\tan ^{-1}$ terdapat pada perlakuan $\left(S_{2}\right)$ yaitu 91,437 gr dan untuk berat segar umbi ha ${ }^{-1}$ terletak pada $\left(S_{2}\right)$ yaitu 1.462 .990 gr atau lebih tinggi sekitar 3,81 gr.

Selain itu juga, pada Tabel 7 dapat dilihat berat segar tanaman, berat segar umbi $\tan ^{-1}$ dan berat segar umbi ha ${ }^{-1}$ pada perlakuan pemupukan kompos antara kontrol $\left(\mathrm{O}_{0}\right)$ dengan pemupukan kompos dosis 5 ton/ha $\left(\mathrm{O}_{1}\right)$ dan dengan pemupukan kompos dosis 10 ton/ha $\left(\mathrm{O}_{2}\right)$ menunjukkan hasil berbeda tidak nyata. Berat segar tanaman tertinggi cenderung terdapat pada perlakuan
$\mathrm{O}_{0}$ baik untuk berat segar tanaman, berat segar umbi $\tan ^{-1}$ maupun berat segar umbi ha $^{-1}$ yaitu 180,917 gr, 91,632 gr dan 1.466 .108 gr.

\section{SIMPULAN DAN SARAN}

\subsection{Simpulan}

Pemupukan ZA dan kompos berpengaruh tidak nyata terhadap kandungan nitrogen tanah, kombinasi pupuk ZA dan kompos menunjukkan pengaruh interaksi sangat nyata terhadap kandungan $\mathrm{Pb}, \mathrm{Zn}, \mathrm{Cu}$ dalam tanah setelah panen. Kandungan $\mathrm{Pb}$ setelah panen tertinggi diperoleh pada perlakuan $100 \mathrm{~kg} \mathrm{~S} / \mathrm{ha}$ dan $5 \mathrm{t}$ kompos/ha $\left(\mathrm{S}_{2} \mathrm{O}_{1)}\right.$ yaitu mencapai $30,07 \mathrm{mg} / \mathrm{kg}$ kemudian kandungan $\mathrm{Zn}$ tertinggi diperoleh pada perlakuan $100 \mathrm{~kg}$ S/ha dan $5 \mathrm{t}$ kompos/ha $\left(\mathrm{S}_{2} \mathrm{O}_{1}\right)$ yaitu mencapai 28,24 $\mathrm{mg} / \mathrm{kg}$ dan kandungan $\mathrm{Cu}$ tertinggi diperoleh pada perlakuan $50 \mathrm{~kg}$ S/ha dan $5 \mathrm{t}$ kompos/ha $\left(\mathrm{S}_{1} \mathrm{O}_{2}\right)$ yaitu mencapai 17,22 $\mathrm{mg} / \mathrm{kg}$. 


\subsection{Saran}

Saran mengenai Pengaruh Pupuk ZA dan Kompos Terhadap Kandungan $\mathrm{Pb}, \mathrm{Zn}$, $\mathrm{Cu}$ dan $\mathrm{N}$ Tanah serta Hasil Tanaman Pada Sistem Budidaya Bawang Merah di Tepi Danau Batur, Kintamani, Bangli ini adalah sebagai berikut: perlunya berperilaku bijak dalam pengembangan sistem budidaya sayuran bawang merah dengan memperhatikan jarak yang ideal antara lahan pertanian dengan sempadan danau sesuai dengan aturan tata ruang wilayah (RTRW) sehingga residu pupuk tidak langsung

\section{DAFTAR PUSTAKA}

Hardjowigeno, S. 2003. Klasifikasi Tanah dan Pedogenesis. Jakarta: Akademika Pressindo. 250 hal.

Indrayani, N. 2006. "Bioiremediasi Lahan Tercemar Profenofos Secara Ex-Situ Dengan Cara Pengomposan" (tesis). Bogor: Sekolah Pasca Sarjana, Institut Pertanian Bogor.

Kuncaka, A. 2004. Pengendalian Pencemaran Lingkungan. Yogyakarta: PSLH-UGM. mengalir ke badan air yang dapat mengakibatkan terjadinya pencemaran air danau, mengurangi sedikit demi sedikit penggunaan pupuk ZA yang mengandung unsur logam berat yang sangat sulit diuraikan oleh mikroorganisme/biota tanah sehingga lingkungan tetap terjaga kelestariannya, dan perlunya meningkatkan kesadaran diri akan pentingnya penggunaan pupuk organik yang lebih ramah lingkungan untuk keberlanjutan lingkungan kedepannya.

Lingga, P. 1989. Petunjuk Penggunaan Pupuk. Jakarta: CV. Yasaguna.

Nugraha, Y. M. 2010. "Kajian Penggunaan Pupuk Organik dan Jenis Pupuk N Terhadap Kadar N Tanah, Serapan N dan Hasil Tanaman Sawi (Brassica juncea L.) Pada Tanah Litosol Gemolong" (tesis). Surakarta: Fakultas Pertanian Universitas Sebelas Maret.

Pare, T. et al. 1999. Extractability of trace metals during composting of biosolids and municipical solid wastes. J. Biol. Fertil. Soils, 29:3137.

Pitojo, S. 2003. Benih Bawang Merah. Yogyakarta: Kanisius. 82 hal 